\title{
Structural damage to houses and buildings induced by liquefaction in the 2016 Kumamoto Earthquake, Japan
}

\author{
Hendra Setiawan ${ }^{1,2^{*}}$ (D, Y Yko Serikawa ${ }^{1}$, Mitsuru Nakamura ${ }^{1}$, Masakatsu Miyajima ${ }^{1}$ and Masaho Yoshida ${ }^{3}$
}

\begin{abstract}
Background: In April 2016, Kumamoto City, Japan, and its surroundings were hit by a sequence of strong and devastating earthquakes including two significant events, one on April 14 ${ }^{\text {th }}, 2016$, at 21:26 JST (Mw6.2) and the other on April 16 ${ }^{\text {th }}, 2016$, at 01:25 JST (Mw7.0). These disasters caused 120 fatalities (including indirect fatalities), 2337 people injured and 177,914 residential houses were damaged. This paper aims to ascertain the damage to residential houses and buildings caused by liquefaction during this earthquake and suggests possible mitigation methods.

Results: Field reconnaissance was conducted in the target area on May $27^{\text {th }}-30^{\text {th }}, 2016$. The post-earthquake inclination angle and the tilt direction of 68 affected houses and buildings in the liquefied sites in Kumamoto City were measured by using a laser rangefinder (Leica DISTO D 510). Ground structure and condition were also determined from topographic maps, bore data and the calculated liquefaction resistance factor, $F_{L}$.

Conclusions: Based on this investigation, the inclination angle of the houses in the target area seems to be related to the type of building structure and their foundation as well to the local ground composition. The tilt direction has a tendency to be associated with the location of the nearby river. The results presented could be useful to develop future liquefaction mitigation measures for detached residential houses.
\end{abstract}

Keywords: The 2016 Kumamoto earthquake, Liquefaction, Field investigation, Residential houses and building damage, Inclination angle

\section{Background}

At 21:26 JST on April $14^{\text {th }}, 2016$, a strong earthquake of Mw6.2 with focal depth $11 \mathrm{~km}$ below the ground surface struck along the Hinagu fault in Kumamoto Prefecture, on the island of Kyushu, Japan. The strongest ground motion recorded was about 1590 gal in Mashiki Town. This earthquake proved to be merely a foreshock. Twenty-eight hours later, on April $16^{\text {th }}, 2016$, at 01:25 JST, on the Futagawa Fault zone in the same area, a stronger earthquake of Mw7.0 occurred with focal depth of $12 \mathrm{~km}$. The maximum ground motion recorded was about $1791 \mathrm{gal}$ in the town of Ozu. It was also reported that there had been a number of aftershocks continued

\footnotetext{
* Correspondence: hendra3909@gmail.com

${ }^{1}$ Kanazawa University, Kakuma-Machi, Kanazawa-Shi, Ishikawa Prefecture 920

1192, Japan

${ }^{2}$ Tadulako University, Bumi Tadulako Tondo Campus, Palu, Central Sulawesi

94118, Indonesia

Full list of author information is available at the end of the article
}

and some of these were quite large with an intensity greater than Mw5. Figure 1a shows the location of the earthquake epicenter (Anon 2016a) and Fig. 1b and c show the estimated seismic intensity distribution for the two major earthquakes, foreshock and mainshock, respectively (Anon 2016b) and (Anon 2016c).

Due to these earthquakes, much damage was triggered by ground liquefaction that occurred in Kumamoto City and surrounding area of the Kumamoto Prefecture, such as rupturing and cracking of the ground surface and ground subsidence which resulted in the settlement of buildings and residential houses. In many major previous earthquakes, the resulting liquefaction often caused damage through differential settlement which eventually led to permanent tilting of buildings and structural damage as seen in the 2011 Great East Japan earthquake disaster. Massive liquefaction-induced damage appeared in the city of Urayasu, where more than 9000 residential houses were affected. This major catastrophe leads to an 


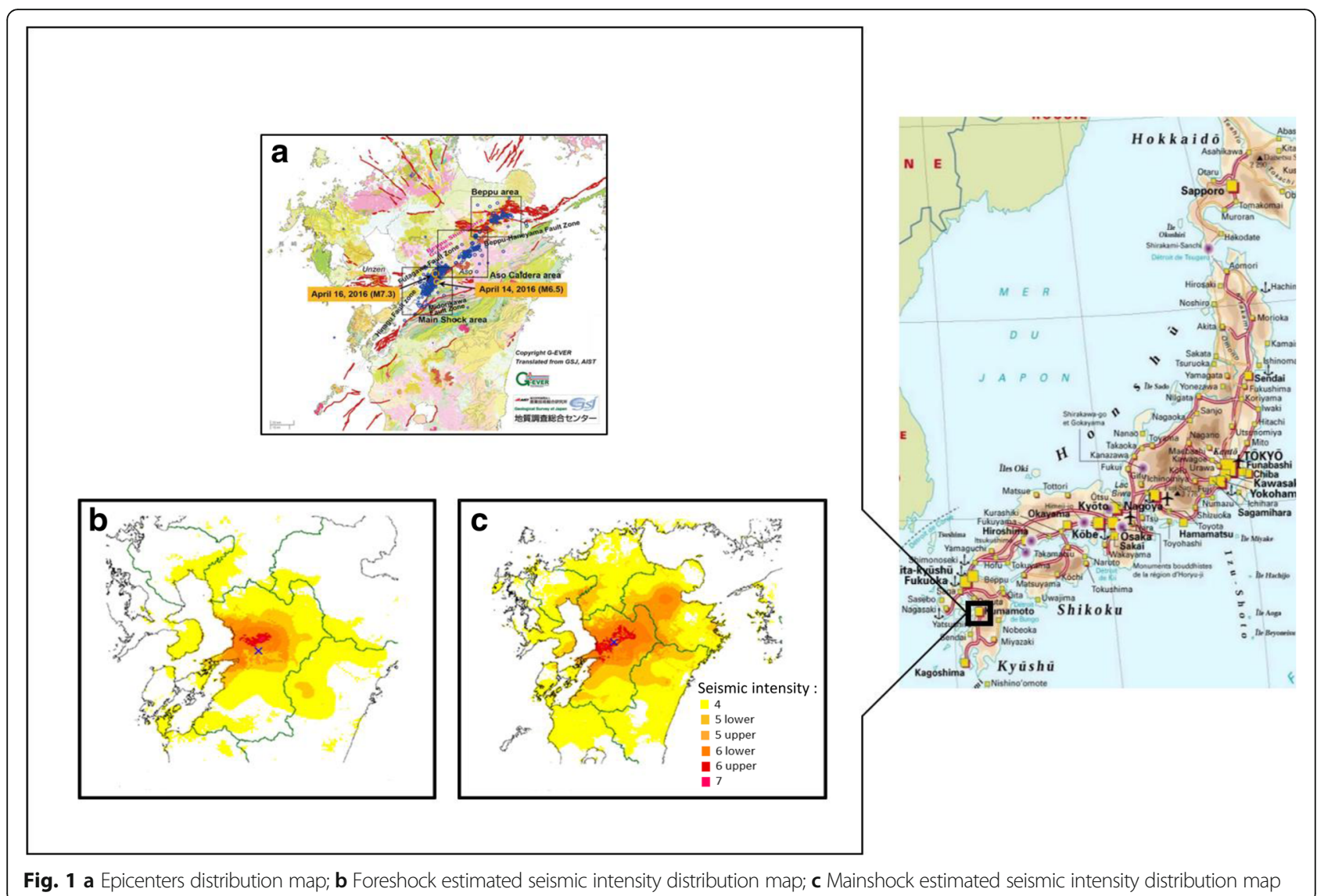

awareness and the importance of safe housing design, particularly against liquefaction. As a result, research related to liquefaction countermeasures became more intensified. Currently, many companies and research institutes are working on developing liquefaction countermeasure for buildings and for residential houses. Several researches and studies have been conducted related to the impact of liquefaction on residential houses during earthquakes, such as the 2010-2011 Christchurch earthquakes (Cubrinovski et al. 2012), the 2011 Tohoku Pacific earthquake (Tokimatsu \& Katsumata 2012) and the much earlier study of the 1990 Luzon earthquake (Tokimatsu et al. 1994). Various liquefaction countermeasure methods had been proposed, for example, implementing shallow ground improvement (Tani et al. 2015), using a sandy soil layer (Koseki et al. 2015), installing sheet-pile walls around the housing foundations (Rasouli et al. 2015) and by using log pile under foundations (Yoshida et al. 2012).

Liquefaction-induced damage also occurred and was a serious problem in certain areas in Kumamoto City during the 2016 Kumamoto earthquake. Building on previous experience, field reconnaissance was conducted in the target area from May $27^{\text {th }}$ to $30^{\text {th }}, 2016$ to investigate the effects of liquefaction on differential settlement and tilting of buildings and residential housing. In this field investigation, information and data were obtained by measuring the structural inclination angles and their direction. In addition, interviews of affected parties in the southern and eastern region of Kumamoto City, where a lot of liquefaction-induced damage reportedly occurred were also undertaken.

The inclination direction and angle of 68 houses and buildings were measured. Using the field survey data, combined with ground sounding data of the surveyed sites, the liquefaction risk was estimated and will be used to clarify the relationship between liquefaction damage and ground condition. Furthermore, it is may also be useful to develop new liquefaction countermeasures for residential houses. Figure 2 displays the liquefaction points and liquefaction-induced damage confirmed in Kumamoto City by the field survey (Shigeki et al. 2016). One of the examples of liquefaction occurrence can be seen in Fig. 3, in which the house experienced ground subsidence due to liquefaction and became tilted.

\section{Methods}

Outline of the survey

In order to observe the impact of liquefaction on residential houses and buildings in the 2016 Kumamoto 


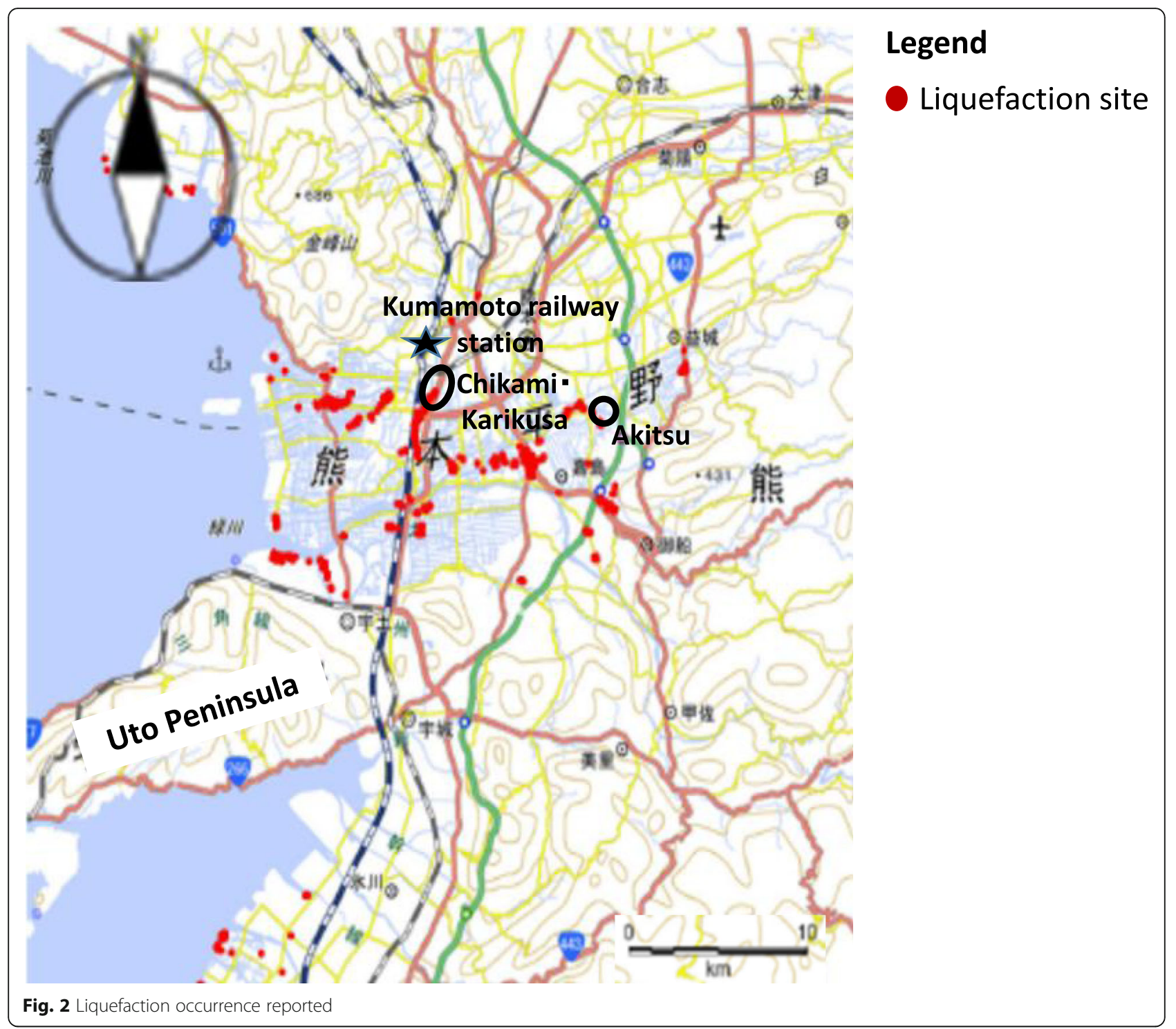

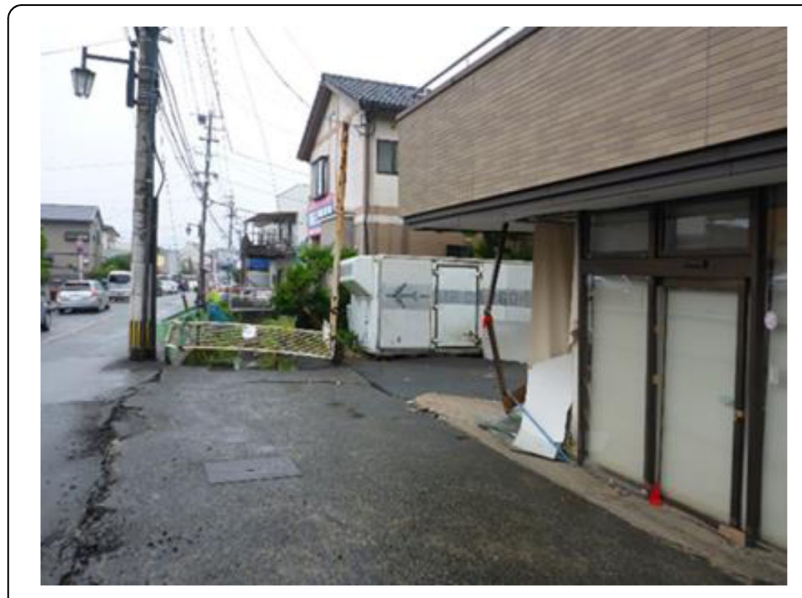

Fig. 3 Example of ground subsidence due to liquefaction
Earthquake, measurement of the tilt angle and tilt direction of 68 houses and buildings were performed in Kumamoto City such as Akitsu, Chikami, and Karikusa where the damage to the tilted houses was marked. The surveyed sites can be seen in Fig. 4. as well as in the topography classification map of Kumamoto City which was published at the J-SHIS earthquake hazard station shown in Fig. 5 (Anon 2016d). As can be seen on this map, the Akitsu area consists of marshland, while Chikami and Karikusa areas are composed of natural embankments as well as marshland. Both of these regions are mostly formed from sand and have shallow groundwater tables. Due to these geological factors, these areas are liquefaction prone during earthquakes.

In this field survey, the tilt angle and tilt direction of the outer walls of the buildings were measured using a laser rangefinder (Leica DISTO D 510). Figure 6 shows 

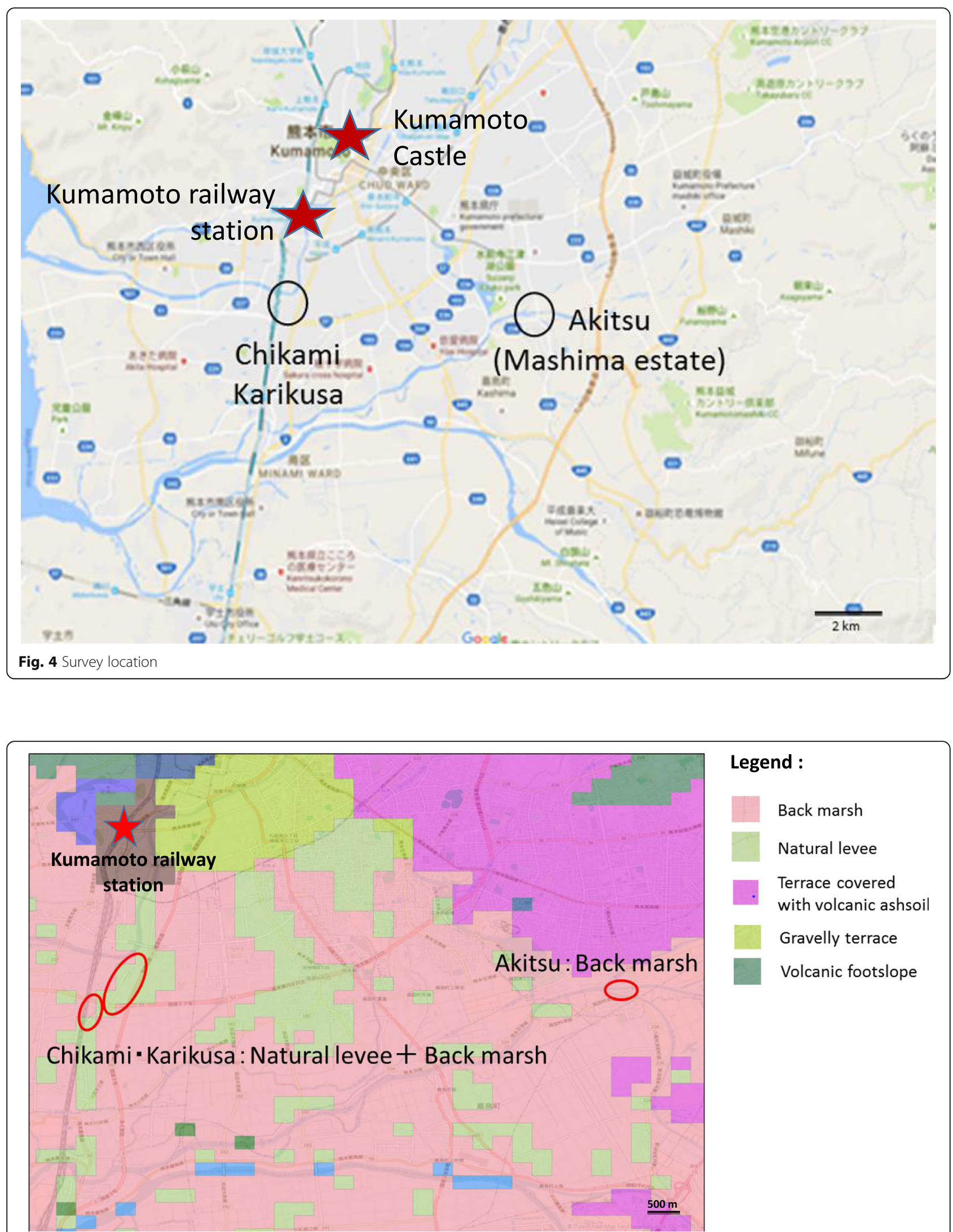

Legend :

Fig. 5 Topography classification map of Kumamoto City 


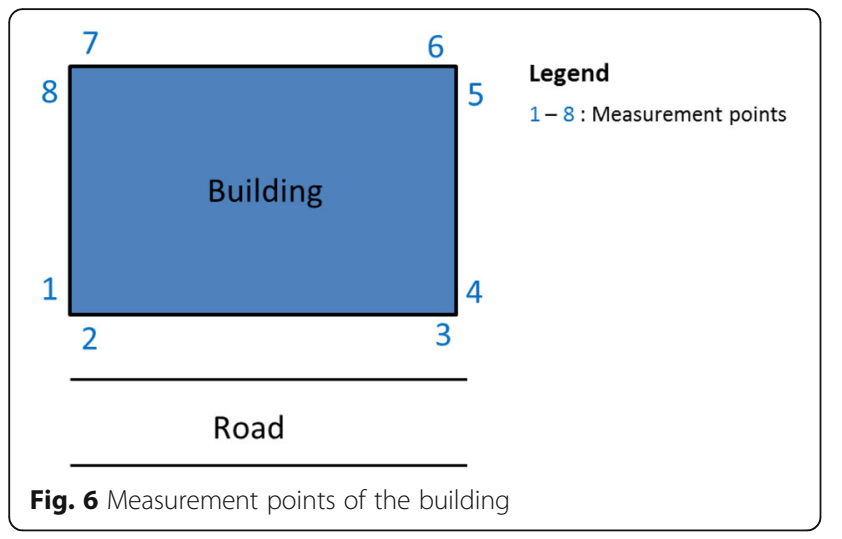

the measurement loci of the houses. To obtain more comprehensive data about the situation at the time of the earthquake and liquefaction occurrences such as sand boiling, interviews of the residents was also undertaken.

Based on the survey results, the relationship between ground geology, building structure and foundation type and the tilt of the structures will be clarified. It is hoped that these findings can be used in the future to develop liquefaction countermeasure methods, particularly for residential houses.

\section{Results}

\section{Akitsu area}

The first location surveyed was Mashima the residential complex in Akitsu, which is located along the riverbank on the south side of the Kiyama River. The ground structure of these areas was also examined by using the site bore data and that of the surrounding area. In addition, using bore data, soil classification and SPT Nvalue, the liquefaction resistance factor, $\mathrm{F}_{\mathrm{L}}$ at the designed horizontal seismic intensity of $\mathrm{K}_{\mathrm{hgL}}=0.3$ was calculated to determine the liquefaction potential of the ground.

Figure $7 \mathrm{a}$ shows the location of the bore $\log$ while Fig. $7 \mathrm{~b}$ presents borehole data obtained at Akitsu. As can be seen in this figure, the groundwater level is $2 \mathrm{~m}$ below the ground surface. The embankment layer lies at a depth of $6.2 \mathrm{~m}$ and at a depth of more than $6.2 \mathrm{~m}$, the ground is composed of sand and silt layers. Bore data at this site were available only to a depth of $10 \mathrm{~m}$, but this data was sufficient to show that the ground consists of an embankment and sand layers which has the potential to liquefy. The calculated SPT N-value showed that the ground was in a very loose condition. The calculation result of the safety factor against liquefaction, $F_{L}$, in Akitsu can be seen in Fig. 7c. Based on the resultant $F_{L}$ value, the Akitsu area has a low risk of liquefaction to a depth of $5 \mathrm{~m}$, as $\mathrm{F}_{\mathrm{L}}$ values are higher than 1 . In contrast, it has a high potential for liquefaction at a depth of more than $6 \mathrm{~m}$ since it is composed of sand and sandy silt layers with an $\mathrm{F}_{\mathrm{L}}$ value lower than 1 .

Eight houses were measured in this area. Figure 8 shows the measurement results of their tilt angle and tilt direction. In this figure, the tilt angle is indicated by a color difference for every $0.5^{\circ}$ and the direction of inclination is marked by an arrow. The tilt angle used is the largest angle of all points measured in each house. Interestingly, a few houses assessed in this area were inclined in the same direction, which was the location of the river. This implies that the damage was caused not only

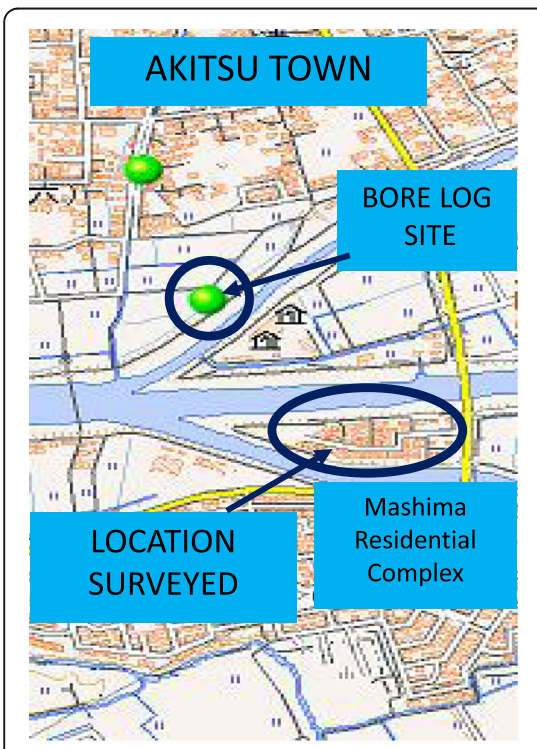

a

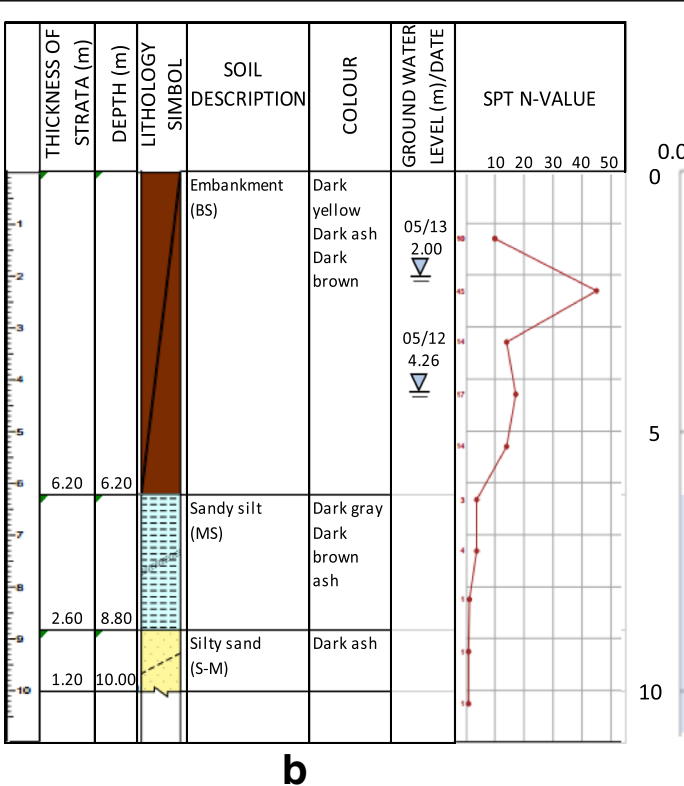

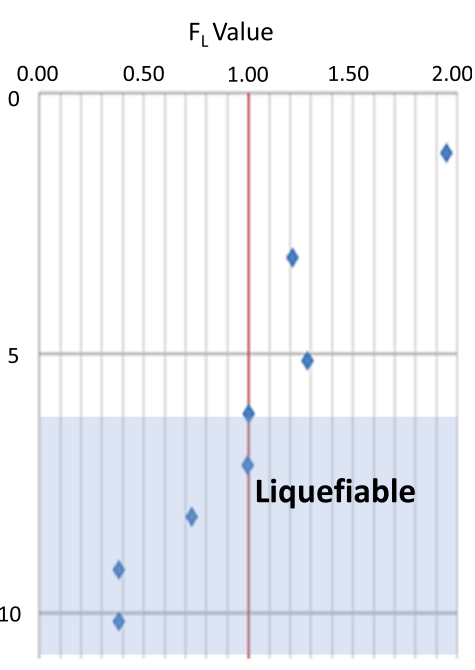

C

Fig. 7 a Bore log site in Akitsu; b Borehole data obtained in Akitsu; c FL values calculation result for Akitsu area 


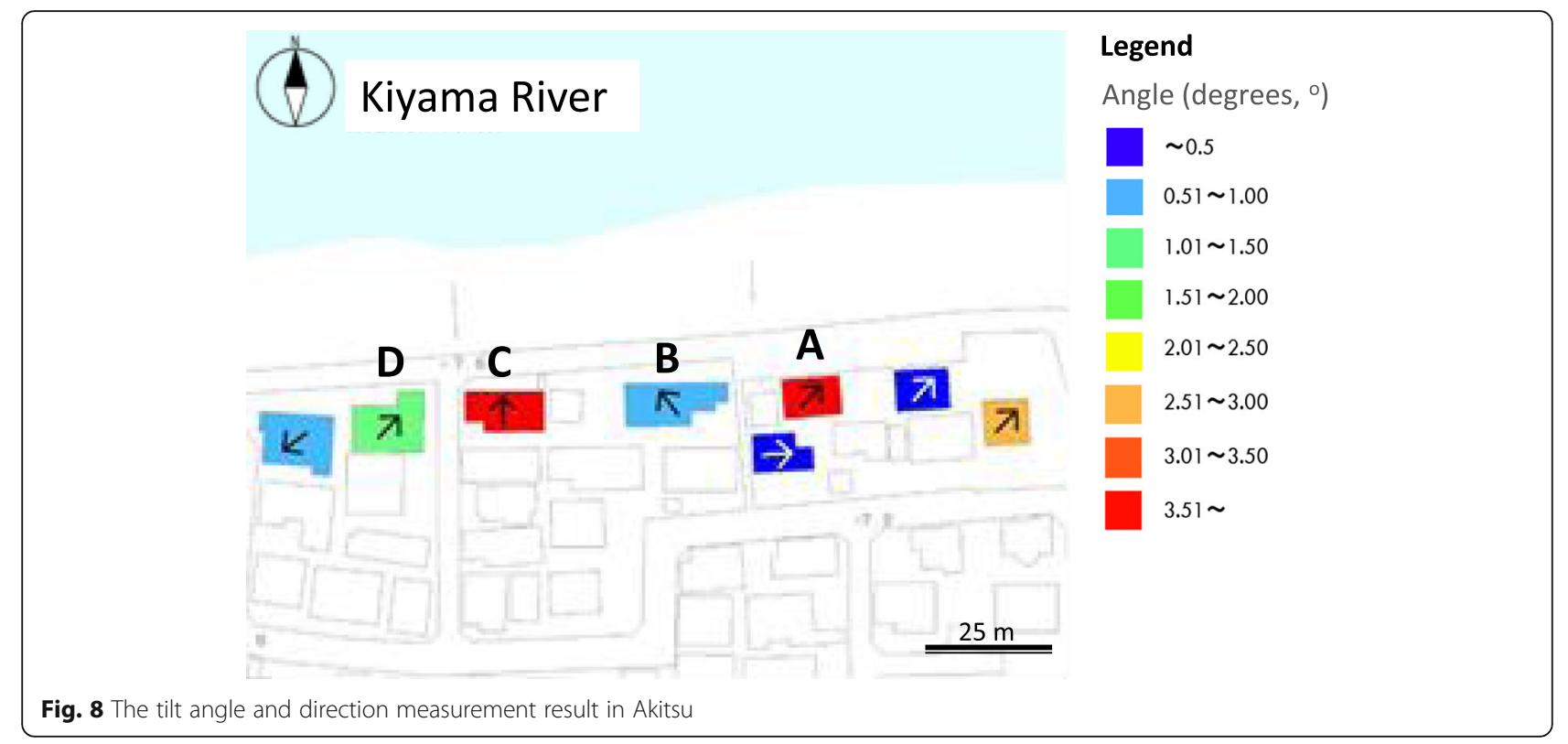

by the subsided soils under the structure but also by the liquefaction occurrence at the riverside area located in front of the houses.

Figure 9 shows the state of the house after the earthquake struck and shows that the house became tilted toward the river. Furthermore, as can be seen in Fig. 10, the lateral movement also occurred toward the river side at this site. As a result, adjacent houses tend to be tilted in the same direction with a lateral spreading direction. Figure 11 presents the summary of the structure types and the damage in this area. As for building A, it was inclined $3.6^{\circ}$ to the north and $3.7^{\circ}$ to the east as there was substantial ground subsidence on the north side and different settlement of the foundation occurred. Ground subsidence at the north side also occurred in buildings $\mathrm{C}$ and $\mathrm{D}$ and similarly to building $\mathrm{A}$, these buildings tilted to the north. Although

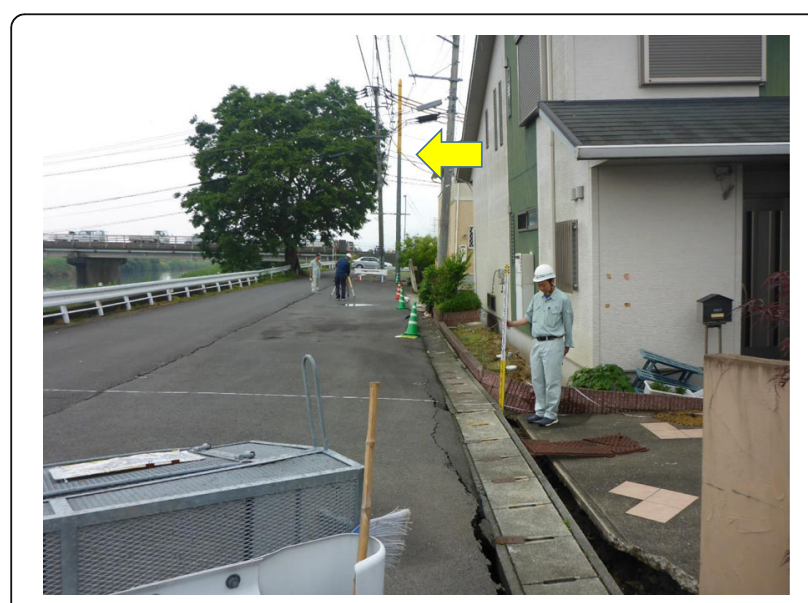

Fig. 9 The tilt condition of the house in Akitsu after the earthquake struck ground subsidence occurred, building B only experienced minor inclination and minor vertical gap development due to the insignificant differential settlement of its foundation. This is because this building was supported by a foundation of piles. Figure 12 shows the pile foundations that support building B. Based on this result, it is thought that the foundation type also influenced the degree of inclination of building structures.

\section{Chikami and Karikusa area}

Chikami and Karikusa are located in the southern part of Kumamoto City. Figure 13a and b show the bore log site and bore data acquired in Chikami and Karikusa area, respectively. The depth of the groundwater level is as shallow as $2.15 \mathrm{~m}$. The soil layers are composed of landfill from 0 to $1.5 \mathrm{~m}$, sand and silt from $1.5 \mathrm{~m}$ to

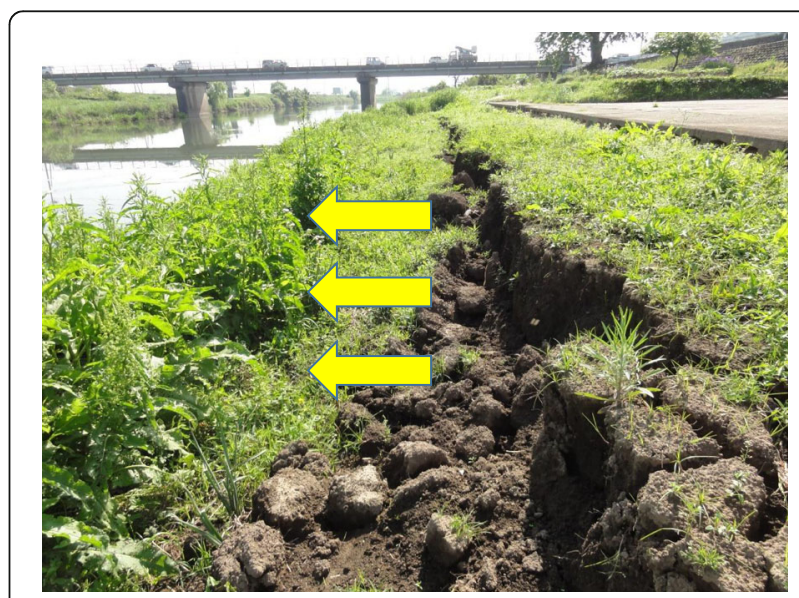

Fig. 10 The occurrence of lateral spreading at the river side, Akitsu 


\begin{tabular}{|c|c|c|c|c|}
\hline Building & a & b & C & C \\
\hline Photo & & & & \\
\hline $\begin{array}{c}\text { Structure } \\
\text { Type }\end{array}$ & $\begin{array}{c}\text { Wooden frame, } \\
\text { 2 storey }\end{array}$ & $\begin{array}{c}\text { Steel frame, } \\
2 \text { storey }\end{array}$ & $\begin{array}{c}\text { Wooden frame, } \\
\text { 2 storey }\end{array}$ & $\begin{array}{c}\text { Wooden frame, } \\
2 \text { storey }\end{array}$ \\
\hline $\begin{array}{c}\text { Inclination } \\
\text { damage }\end{array}$ & $\begin{array}{c}3.6^{\circ} \text { to the North, } \\
3.7^{\circ} \text { to the East }\end{array}$ & $\begin{array}{c}\text { Minor inclination } \\
\text { (less than } 1^{\circ} \text { ) }\end{array}$ & $3.6^{\circ}$ to the North & $1.5^{\circ}$ to the North \\
\hline
\end{tabular}

Fig. 11 The summary of the structure type and damage level (Buildings A, B, C and D in Fig. 8) in Akitsu

$20 \mathrm{~m}$ depth below the ground surface. It can be seen that SPT N-value near to the ground surface is also very low, so it can be said that this ground has a high risk of liquefaction, especially from the ground surface down to a depth of around $12.5 \mathrm{~m}$.

Figure 13c gives the $F_{L}$ values for Chikami and Karikusa areas. Based on calculated $F_{L}$ value its potential to liquefy is moderately high to a depth of about $12.5 \mathrm{~m}$ below the ground surface as it is composed mostly of sand and has $F_{L}$ values of less than 1 , specifically near the surface. Generally, the potentially liquefiable ground surface may lead to structural damage related to differential settlement and structure tilting because sand boiling has a high potential to take place.

In order to ascertain ground conditions in this area, geological profiles of other two bore logs are observed in the adjacent site. The result obtained were much the same, as shown in Figs. 14 and 15.

It was determined that the liquefaction damage in this area was distributed along a longitudinal strip because there was a former river on the north-south side of this site. This liquefiable zone was spread over $5 \mathrm{~km}$ in length and 50 to $100 \mathrm{~m}$ in width, allowing ground subsidence and sand boiling. Figure 16 shows a guide

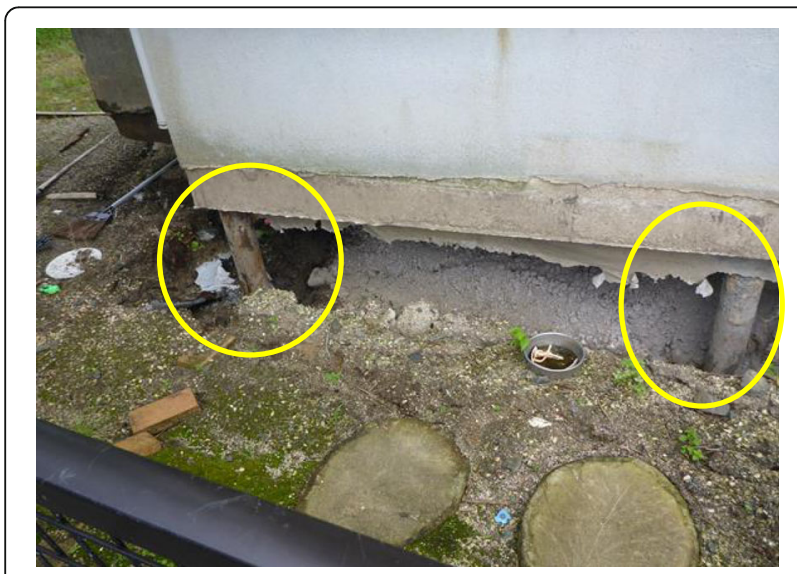

Fig. 12 The pile foundation of the house which experienced minor inclination in Akitsu pillar the side of the road naming it as the Chikami bridge. It substantiates the assumption that this area was previously a river and provides a major reason why this area suffered severe damage due to liquefaction.

Figure 17 shows the measurement results of the inclination angle and tilt direction of the buildings in Chikami area. There is a tendency for houses experiencing large tilt angles were located on the adjacent site. It can also be seen from this figure that the direction of inclination is to the southeast where the river used to be. Structure types and building damage are summarized in Fig. 18 . Differential settlement occurred in both steel framed and wooden framed buildings. The four buildings, A, B, $\mathrm{C}$, and $\mathrm{D}$ are taller than other building in their vicinity, as a result, the tilt angle and the damage inflicted were substantial. Buildings B and C were tilted so as to appear to be attracted to each other like magnets. This was probably caused by the combined weight of the two adjacent buildings resulting in a greater settlement on the neighboring side. It also seems that the non-uniform settlements were influenced by the weight of the structure and the position of its center of mass. For building $\mathrm{D}$, the north side wall was severely damaged resulting in a large inclination.

Figure 19 gives the tilt angles and tilt directions of the houses in the Karikusa area. Similarly, in this area, many buildings experienced an inclination toward the east. Figure 20 shows the summary of the structural forms and building damage in this area. The building with the largest inclination angle is building B, which was a one storey building. There was no significant wall or structural damage to this building, but a lot of boiled sand traces remained around the building, indicating a large amount of sand boiling had occurred. Buildings A, C, and $\mathrm{D}$ were inclined to the east.

\section{Discussion}

In Akitsu area, using the sounding data and the calculated $F_{L}$ value, the ground at a depth of more than $5 \mathrm{~m}$ below the ground surface, was categorized as potentially liquefiable. Liquefaction that occurred in this 


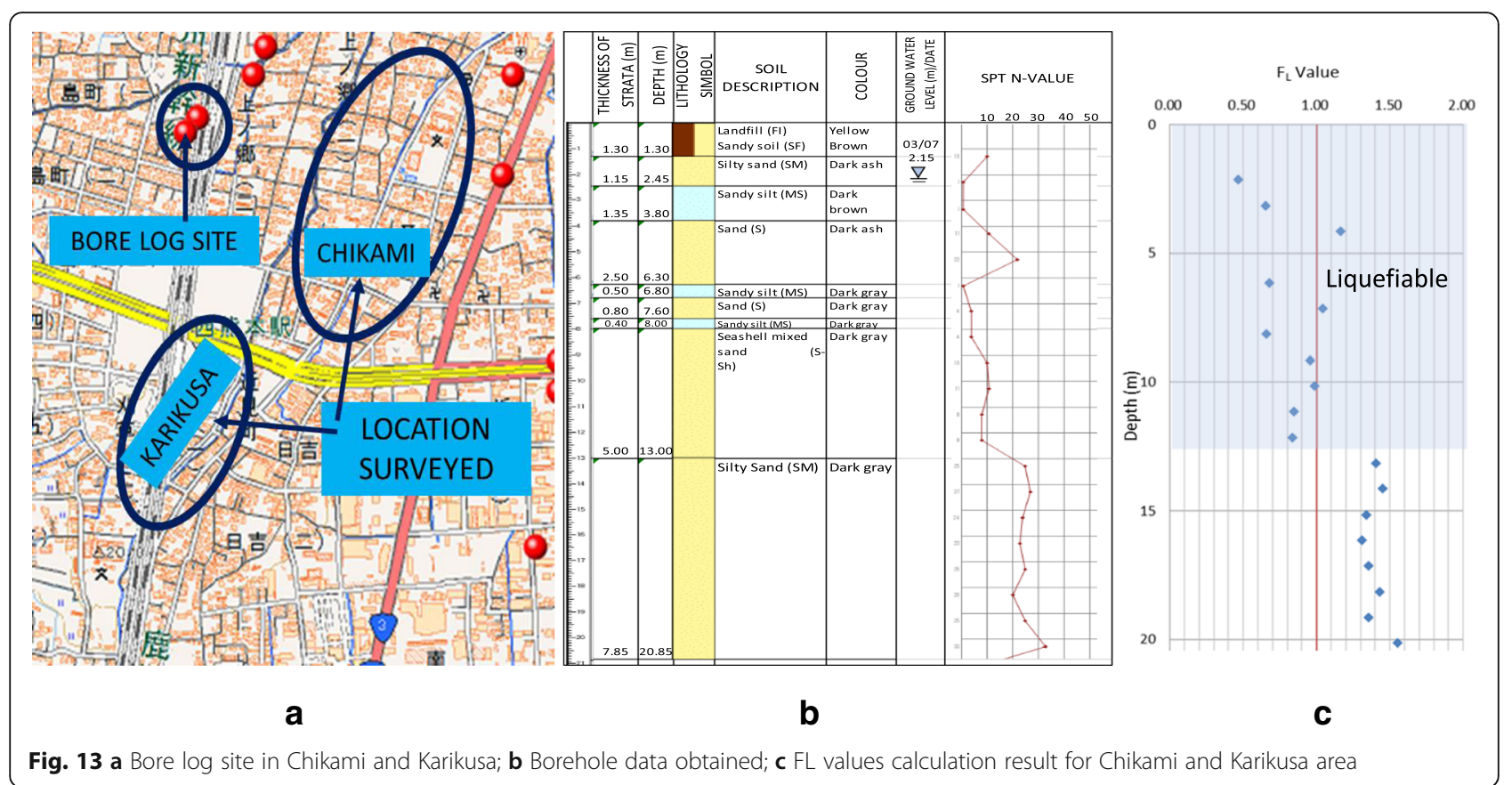

area was mainly affected by the very loose silt and sand layer at a depth of around $6 \mathrm{~m}$ below the ground surface, and the existence of the Kiyama river as well. It can be seen on the ground, the lateral movement appeared on the riverside area and also soft ground with high potential of liquefaction was present near the ground surface. As a result, ground subsidence and differential settlement of houses did indeed occur in this location.
In Chikami and Karikusa area, one of the liquefaction occurrences was sand boil. Boiled sand traces remained at the side of the road and around the houses surveyed. This sand boiling took place because the ground at this area is mostly composed of the sand, and from the ground surface to a depth of $12 \mathrm{~m}$ was categorized as potentially liquefiable. Furthermore, liquefaction was also affected by the former river on the north-south side of this area. This potentially liquefiable sand on the

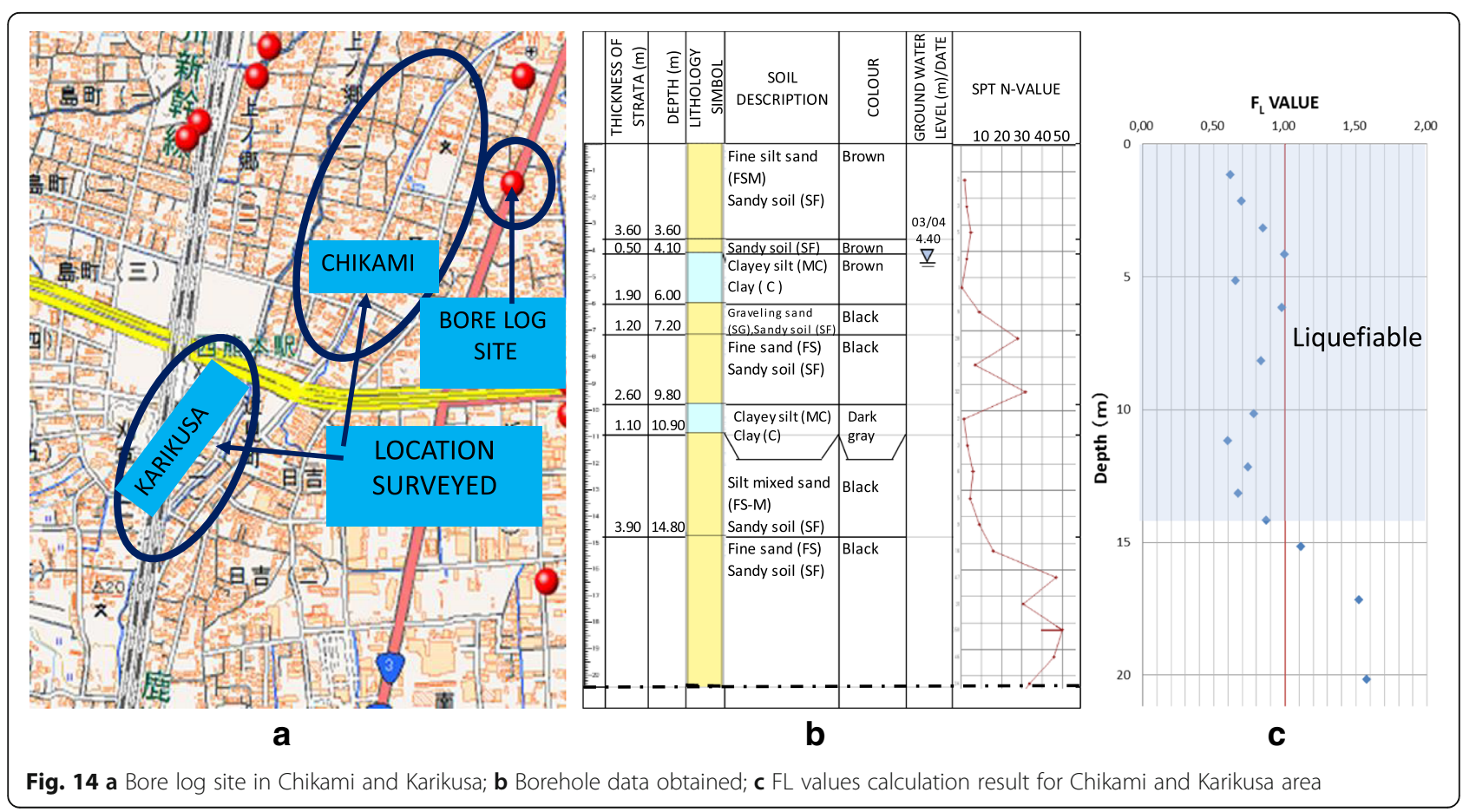




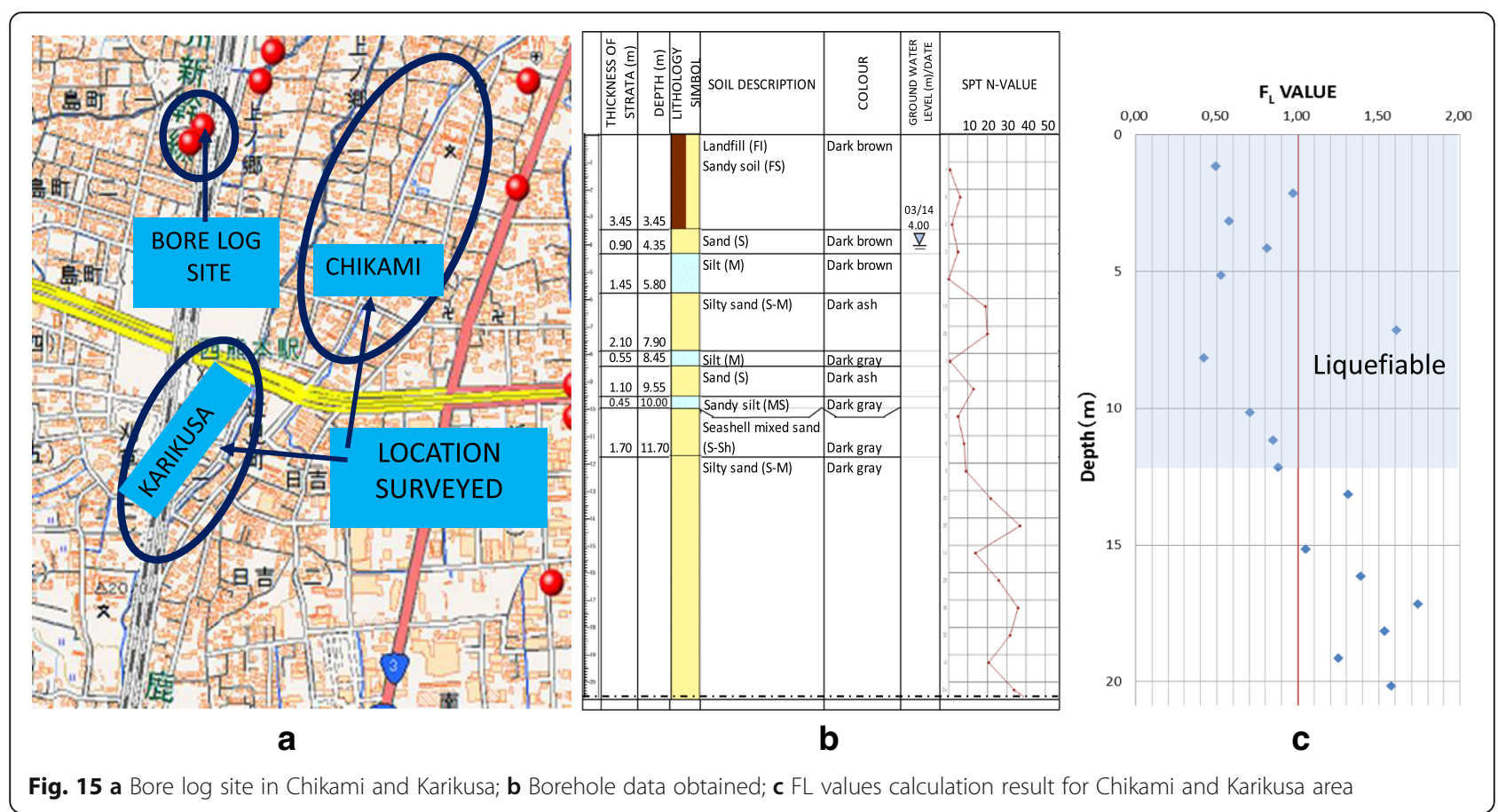

ground surface may lead to structural damage related to structure tilting due to sand boiling.

Based on this, the liquefaction risk determined using bore data and the value of $F_{L}$ was roughly in agreement with the damage that occurred. Therefore, in order to mitigate liquefaction in the future, it will be necessary to detect the location of weak underground layers. The degree of the damage sustained by houses even within nearby locations depended on the type of building structure and its foundation type. Consequently, in order to select appropriate liquefaction mitigation measures for existing structures such as detached residential houses, it is necessary to consider the characteristics not only of the structure but the geological condition of the ground as well.

In the interview with the residents, many considered moving due to a high risk of re-liquefaction of the ground. It was thought there was little likelihood of applying countermeasures to their houses because of the associated difficulties in doing so and the high cost of the countermeasures. In addition, residents felt uncomfortable with a house tilt angle of $1^{\circ}$ or more and even worse, the house became hard to live in if the inclination angle exceeding $2^{\circ}$.

Previously, in the 2011 Great East Japan Earthquake, enormous liquefaction damage occurred in Urayasu City,

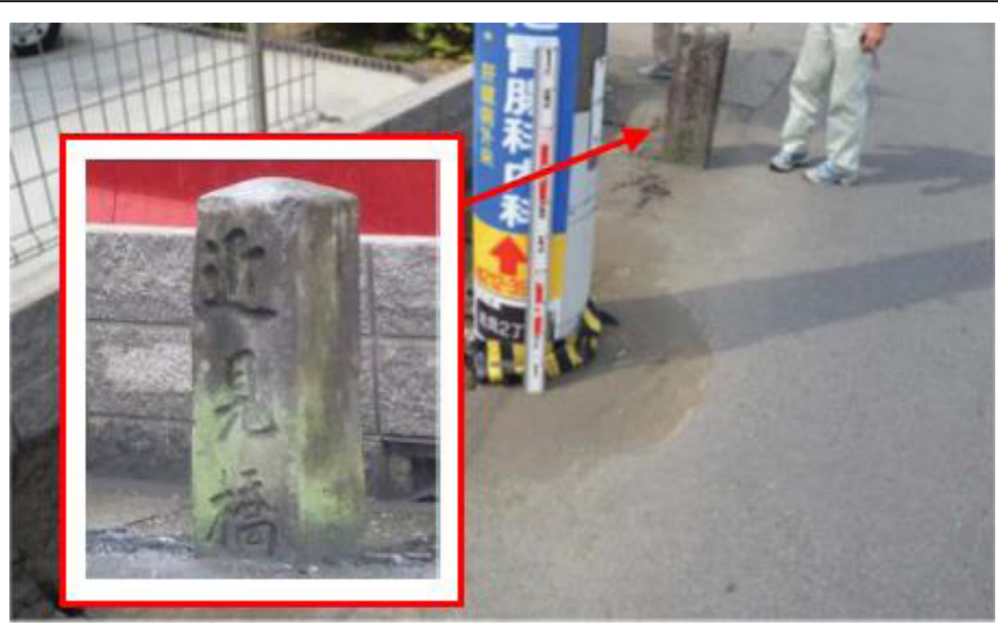

Fig. 16 The guide pillar of the former Chikami bridge 


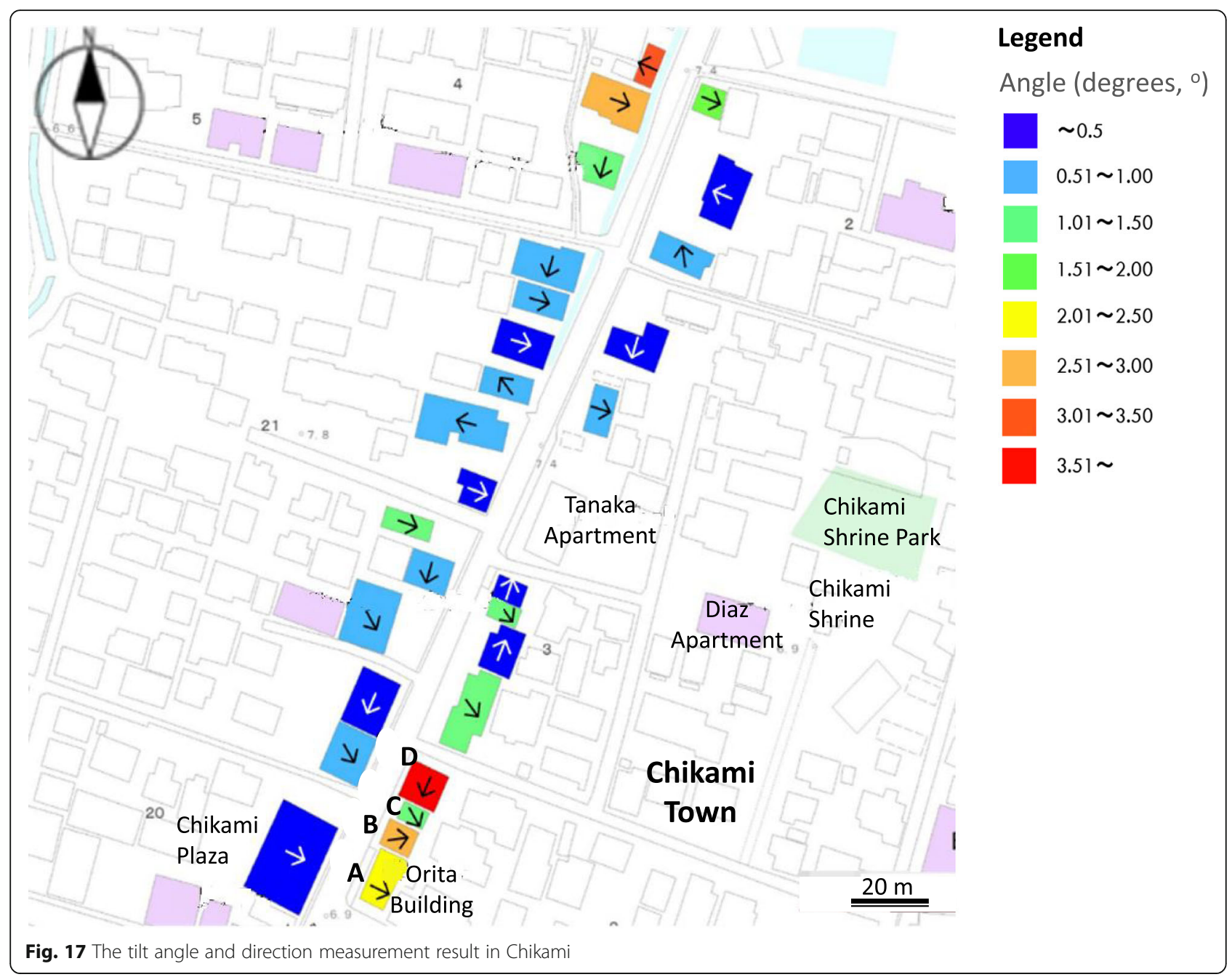

Chiba Prefecture, in which was about $85 \%$ of the city was damaged. Because of the huge area that suffered liquefaction, a large-scale liquefaction countermeasure was undertaken, in the form of underground walls. On the other hand, Kumamoto City, unlike Urayasu City, the occurrence of liquefaction was not centralized in one large area but scattered in small separate regions. Even though some of the buildings were situated in neighboring areas, the damage that occurred due to liquefaction to each building also varied, depending on the factors mentioned earlier, for example, the type of the structure and its foundation type.

Based on the different conditions of liquefaction that occurred in these two cities, the recommended mitigation

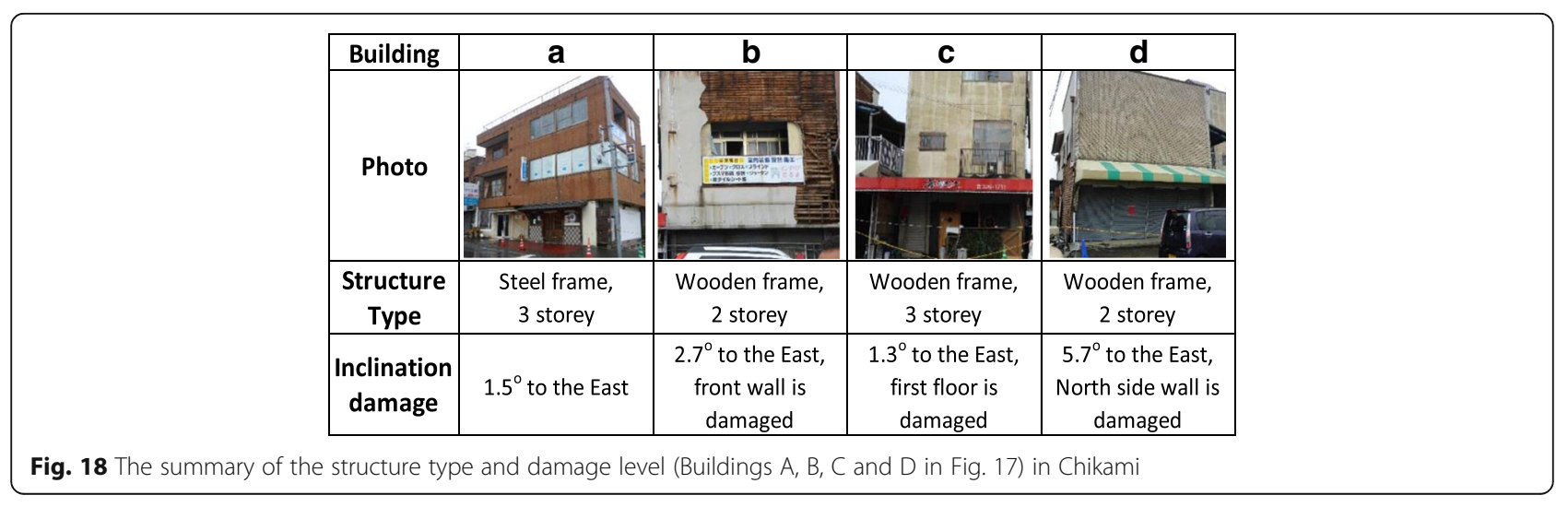




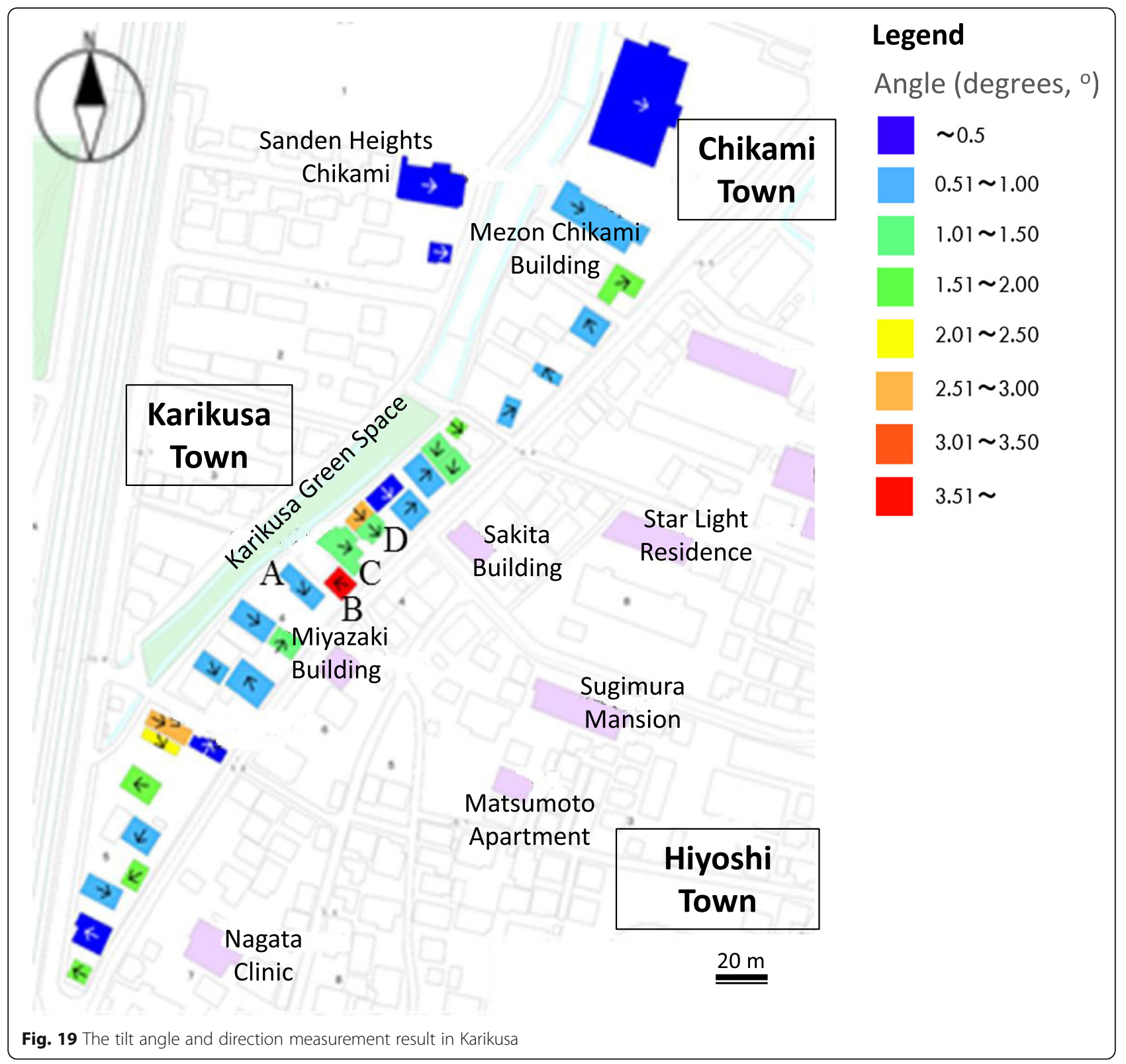

\begin{tabular}{|c|c|c|c|c|}
\hline Building & $\mathbf{a}$ & b & C & d \\
\hline Photo & 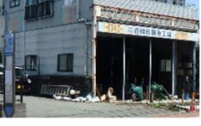 & & 或 & $=\frac{5}{2}$ \\
\hline $\begin{array}{c}\text { Structure } \\
\text { Type }\end{array}$ & $\begin{array}{c}\text { Steel frame, } \\
2 \text { storey }\end{array}$ & $\begin{array}{c}\text { Wooden frame, } \\
1 \text { storey }\end{array}$ & $\begin{array}{c}\text { Steel frame, } \\
2 \text { storey }\end{array}$ & $\begin{array}{c}\text { Wooden frame, } \\
2 \text { storey }\end{array}$ \\
\hline $\begin{array}{c}\text { Inclination } \\
\text { damage }\end{array}$ & $\begin{array}{l}\text { Minor inclination } \\
\left.\text { (less than } 1^{\circ}\right)\end{array}$ & $3.6^{\circ}$ to the West & $1.3^{\circ}$ to the East & $1.3^{\circ}$ to the East \\
\hline
\end{tabular}

Fig. 20 The summary of the structure type and damage level (Buildings A, B, C and D in Fig. 19) in Karikusa 
methods applicable to Kumamoto City and surrounding areas will be different to the methods that employed in Urayasu City. It is thought that will be useful to devise and develop liquefaction countermeasures for existing detached residential houses and buildings, in addition to the large-scale mitigation technique applied in Kumamoto City and nearby areas.

Nowadays, we are doing a research related to liquefaction countermeasure methods that can be utilized for detached residential houses.

\section{Conclusion}

In the field reconnaissance, 68 houses were measured and the tilt angle and tilt direction were described on the map presented. Although this survey was in a narrow area, it was found that there was a great variance in the degree of inclination of the buildings within that area.

The extent of the damage was found to relate to such factors as differences in the type of building structure and their foundations, the weight of the structure as well as the ground condition. As a result, the degree of the damage differed from building to building within the same location, for example, while buildings supported by conventional foundations experienced large inclination, the pile-supported building only suffered minor inclination. In addition, it was found that topography affects the direction of inclination which in this case was mostly toward the river location. Furthermore, some of the houses and buildings which experienced large tilt angles were located on the adjacent site. In order to devise and develop a new and effective liquefaction countermeasures for residential houses, it is recommended that a comprehensive investigation be undertaken taking into consideration such factors as implementation methods, costs, material availability as well as structure and foundation type while not forgetting the underlying geological structure of the ground as well the surrounding topography. These considerations may produce liquefaction countermeasure methods suitable for detached residential houses.

\section{Acknowledgements}

This research was financially supported by JSPS KAKENHI Grant Number: 25289135. The authors thank Mr. Naoki Nomura of the Nihonkai Consultant Co. Ltd. and Mr. Kazutaka Shichiroumaru of the Kokudo Kaihatu Center Co. Ltd. for supported in this field reconnaissance. The authors also thank Directorate of Resources for Science, Technology, and Higher Education, Ministry of Research, Technology and Higher Education of Indonesia for the scholarship.

\section{Authors' contributions}

HS, YS, MN, MM, and MY participated in the field reconnaissance and discussed the results of the survey. HS drafted the manuscript. YS and MN prepared the topographic map of Kumamoto City and boring data processing. All authors have read and approved the final manuscript.

\section{Publisher's Note}

Springer Nature remains neutral with regard to jurisdictional claims in published maps and institutional affiliations.

\section{Author details}

${ }^{1}$ Kanazawa University, Kakuma-Machi, Kanazawa-Shi, Ishikawa Prefecture 920 1192, Japan. ${ }^{2}$ Tadulako University, Bumi Tadulako Tondo Campus, Palu, Central Sulawesi 94118 , Indonesia. ${ }^{3}$ National Institute of Technology, Fukui College, Geshi-chou, Sabae, Fukui Prefecture 916 8507, Japan.

Received: 10 December 2016 Accepted: 30 March 2017

Published online: 05 April 2017

References

Anon. 2016a. Distribution of epicenters plotted on geological maps in Kumamoto Prefecture. Available at: http://g-ever.org/updates/?p=285. Accessed 29 Nov 2016.

Anon. 2016b. Estimated seismic intensity distribution map (April 14th, 2016). Available at: http://www.data.jma.go.jp/svd/eew/data/suikei/201604142126 741/201604142126 741 1.html. Accessed 29 Nov 2016.

Anon. 2016c. Estimated seismic intensity distribution map (April 16, 2016). Available at: http://www.data.jma.go.jp/svd/eew/data/suikei/201604160125 741/201604160125_741_1.html. Accessed 25 Nov 2016.

Anon. 2016d. Kumamoto topography classification map. Available at: http://www. j-shis.bosai.go.jp/. Accessed 29 Nov 2016.

Cubrinovski, M., D. Henderson, and B. Bradley. 2012. Liquefaction Impacts in Residential Areas in the 2010-2011 Christchurch Earthquakes, One year after 2011 Great East Japan Earthquake: International Symposium on Engineering Lessons Learned from the Giant Earthquake, 1-14.

Koseki, J., K. Wakamatsu, S. Sawada, and K. Matsushita. 2015. Liquefaction-induced damage to houses and its countermeasures at Minami-Kurihashi in Kuki City during the 2011 Tohoku Earthquake, Japan. Soil Dynamics and Earthquake Engineering 79: 391-400.

Rasouli, R., I. Towhata, and T. Hayashida. 2015. Mitigation of seismic settlement of light surface structures by installation of sheet-pile walls around the foundation. Soil Dynamics and Earthquake Engineering 72: 108-118.

Shigeki, S., K. Wakamatsu, K. Ozawa, and H. Fujiwara. 2016. Liquefied sites during the 2016 Kumamoto Earthquake. Available at: https://confit.atlas.jp/guide/ event-img/jpgu2016/MIS34-26P87/public/pdf. Accessed 29 Nov 2016.

Tani, K., T. Kiyota, K. Matsushita, T. Hashimoto, A. Yamamoto, H. Takeuchi, T. Noda, H. Kiku, and J. Obayashi. 2015. Liquefaction countermeasures by shallow ground improvement for houses and their cost analysis. Soil Dynamics and Earthquake Engineering 79: 401-414.

Tokimatsu, K., and K. Katsumata. 2012. Liquefaction-Induced Damade To Buildings in Urayasu City During the 2011 Tohoku Pacific Eathquake, The International Symposium on Engineering Lessons learned from the 2011 Great East Japan earthquake, 665-674.

Tokimatsu, B.K., H. Kojima, and S. Kuwayama. 1994. Liquefaction-induced damage to buildings in 1990 Luzon earthquake. Journal of Geotechnical Engineering 120(2): 290-307.

Yoshida, M., M. Miyajima, and A. Numata. 2012. Proceedings of the Tenth International Symposium on Mitigation of Geo-disasters in Asia in Matsue Conference, 55-67.

\section{Submit your manuscript to a SpringerOpen ${ }^{\mathcal{O}}$ journal and benefit from:}

- Convenient online submission

- Rigorous peer review

- Immediate publication on acceptance

- Open access: articles freely available online

- High visibility within the field

- Retaining the copyright to your article

Submit your next manuscript at springeropen.com 